\title{
Differences between early versus late correction of Tetralogy of Fallot (TOF) in cardiac Magnetic Resonance (CMR)
}

\author{
Matthias Grothoff*, Janine Hoffmann, Kai Boegershausen, Matthias Gutberlet \\ From 2011 SCMR/Euro CMR Joint Scientific Sessions \\ Nice, France. 3-6 February 2011
}

\section{Introduction}

Tetralogy of Fallot can be repaired with low mortality and most patients reach adulthood. Nevertheless the optimal timing of surgery remains controversial.

\section{Purpose}

To evaluate differences between early versus late correction of Tetralogy of Fallot (TOF) in cardiac Magnetic Resonance (CMR).

\section{Methods}

CMR was performed in 55 patients (20 male) using a $1.5 \mathrm{~T}$ scanner. $\mathrm{RV}$-volumes and pulmonary-regurgitantfractions (PRF) were calculated from standard cinesequences and flow-sensitive gradient-echo images, respectively. Scar tissue was quantified from Delayed Enhancement (DE) imaging. Patients were divided into two groups depending age at total repair (group $1 \leq 1$ year, $\mathrm{n}=25$; group $2>1$ years, $\mathrm{n}=30$ ).

\section{Results}

In 50 patients (91\%) RV image quality was diagnostic for quantification of RV DE. Patients of group 2 demonstrated with a significantly higher RV DE $(\mathrm{p}<0.05)$ compared to group 1 . No differences were found in regard to LV DE, RV size and RV function.

\section{Conclusions}

Patients repaired $<1$ year show a lower amount of fibrous tissue in the RV. This might support the strategy of early repair.

Published: 2 February 2011

doi:10.1186/1532-429X-13-S1-P193

Cite this article as: Grothoff et al:: Differences between early versus late correction of Tetralogy of Fallot (TOF) in cardiac Magnetic Resonance (CMR). Journal of Cardiovascular Magnetic Resonance 2011 13(Suppl 1): P193.
Submit your next manuscript to BioMed Central and take full advantage of:

- Convenient online submission

- Thorough peer review

- No space constraints or color figure charges

- Immediate publication on acceptance

- Inclusion in PubMed, CAS, Scopus and Google Scholar

- Research which is freely available for redistribution

Submit your manuscript at www.biomedcentral.com/submit 